\title{
BRIEF ORIGINAL
}

\section{RELATIONSHIP BETWEEN DAILY PHYSICAL ACTIVITY, RECESS PHYSICAL ACTIVITY, AGE AND SEX IN SCHOLAR OF PRIMARY SCHOOL (*)}

\section{Yolanda Escalante (1), Karianne Backx (2), Jose M Saavedra (1), Antonio Garcia-Hermoso (1) and Ana M Dominguez (1).}

(1) Facultad de Ciencias del Deporte, AFIDES Research Group, Universidad de Extremadura. Caceres.

(2) Cardiff School of Sport, University of Wales Institute. Cardiff. United Kingdom.

(*) This study was funded by European Social Funds (FEDER FUNDS) and the Autonomous Government of Extremadura (Junta de Extremadura, Spain) (PRI08A066, PO10012, GR10171)

The authors report no conflicts of interest.

\begin{abstract}
Background. Sedentary behavior has negative effects on health. School recess playgrounds provide important settings and opportunities for children to engage in physical activity. The aim of this study was to describe the daily physical activity (PA) and physical activity during recess of Primary School children and the relationship with sex and age.

Method. 783 children ( 379 boys and 359 girls; age $=8.5 \pm 1.7$ years; range 6 to 11) participated in the study. Daily PA of each child was measured using a validated questionnaire that was completed by the parents of each child, whilst playground recess PA was measured using accelerometry. An ANOVA was used to determine differences by sex in each age group with confidence intervals and effect sizes. Also MANOVA was used to analyse the main and interaction effects of age and sex on variables. The Scheffe post-hoc test was used for comparisons.

Results. Boys reported higher daily PA levels than girls across all age groups. The differences was bigger in seven $(47,6 \pm 6,5$ vs $42,6 \pm 6,4$ MET/day; $<<0,001)$, eight $(48,5 \pm 8,6$ vs $41,9 \pm 4,6 \mathrm{MET} /$ day; $<<0,001)$ and nine years old $(49,8 \pm 8,3$ vs $44,1 \pm 5,9 \mathrm{MET} /$ day; $\mathrm{p}<0,001)$. Measured recess PA was higher for boys compared to girls at age nine $(28,4 \pm 12,0 \mathrm{vs}$ $23.7 \pm 11,8$ motion counts; $\mathrm{p}<0,039)$, ten $(28,5 \pm 10,8$ vs $23,7 \pm 10,0$ motion counts; $p<0,014)$ and eleven years old $(24,6 \pm 12,2$ vs $20,7 \pm 9,3$ motion counts; $\mathrm{p}<0,047)$.

Conclusion. Daily PA is higher in boys compared to girls across all age groups (six to eleven years old). On the other hand, recess PA was higher only in boys between nine and eleven years.

Key word: Chilhood. Physical activity. Exercise. Health. Sedentary lifestyle. Spain
\end{abstract}

\section{Address:}

Yolanda Escalante

Facultad de Ciencias de 1 Deporte

AFIDES Research Group

Universidad de Extremadura

Avda. Universidad $\mathrm{s} / \mathrm{n}$

10071 Cáceres (Spain)

yescgon@unex.es

\section{RESUMEN}

Relación entre actividad física diaria, actividad física en el patio escolar, edad y sexo en escolares de educación primaria

Fundamento. El sedentarismo tiene efectos negativos sobre la salud. El recreo escolar puede ser una oportunidad para realizar actividad física El objetivo de este estudio fue describir la actividad fisica realizada diariamente y durante el recreo por escolares de Educación Primaria en función del sexo y la edad.

Métodos. Participaron 738 escolares (379 niños y 359 niñas; $8,5 \pm 1,7$ años; rango de 6 a 11 años). Se evaluó la actividad física diaria a través de cuestionario validado cubierto por los padres y la actividad física en el patio durante el recreo a través de acelerometría. Se realizó un ANOVA de una vía para conocer las diferencias entre niños y niñas en cada grupo edad, calculando, además, los intervalos de confianza y el tamaño del efecto. También se realizó un MANOVA para analizar los efectos de la edad y el sexo con post hoc de Sheffé.

Resultados. Los niños mostraron mayores niveles de actividad física diaria que las niñas en todos los grupos de edad, siendo mayor esta diferencia a los siete años $(47,6 \pm 6,5$ vs $42,6 \pm 6,4 \mathrm{MET} /$ día; $\mathrm{p}<0,001)$, a los ocho $(48,5 \pm 8,6$ vs $41,9 \pm 4,6 \mathrm{MET} /$ día; $\mathrm{p}<0,001)$ y a los nueve $(49,8 \pm 8,3$ vs $44,1 \pm 5,9 \mathrm{MET} /$ día; $\mathrm{p}<0,001)$. La actividad física en el patio fue mayor en niños que en niñas a los nueve $(28,4 \pm 12,0$ vs $23,7 \pm 11,8$ motion counts; $\mathrm{p}<0,039)$, diez $(28,5 \pm 10,8$ vs $23,7 \pm 10,0$ motion counts; $\mathrm{p}<0,014)$ y once años $(24,6 \pm 12,2$ vs $20,7 \pm 9,3$ motion counts; $p<0,047)$

Conclusión. En relación a la actividad física diaria, los niños son más activos que las niñas en todas las edades estudiadas (seis a once años). Por su parte, en la actividad física en el patio escolar sólo existen diferencias, a favor de los niños entre los nueve y once años.

Palabras clave: Actividad física. Ejercicio. Salud. Estilo de vida sedentario. Infancia. 


\section{INTRODUCTION}

Well documented research demonstrates the negative effects of high levels of inactivity and the beneficial effects of physical activity on health and well-being in the long term ${ }^{1}$. Sedentary lifestyle is one of the leading causes of chronic diseases, including cardiovascular disease, type 2 diabetes, osteoporosis, and other. Evidence is accumulating that health and well-being in adulthood originates from childhood behavior and lifestyle1. Current guidelines recommend that children and youth people (5-17 years) should engage in 60 minutes or more of daily physical activity mainly aerobic and moderate or vigorous in intensity. Furthermore it is also recommended that children participate in activities that strengthen the musculoskeletal system at least three times a week ${ }^{2}$. Worryingly, the international Health Behavior in Schoolaged Children study ${ }^{2}$, reports that only $27 \%$ of all girls and $40 \%$ of all boys follow these recommendations. Physiological determinants of physical activity in children and teenagers include race, sex, and $\mathrm{age}^{3}$. A recent study shows that Caucasian boys under 10 years old are more active than girls of any age, Caucasian boys over 12 years of age and black children of any age ${ }^{4}$. However there are studies that confirm how physical activity of schoolchildren can be influenced by physical activity of friends $s^{5}$, siblings ${ }^{6}$ and parents ${ }^{7}$ or by parental support ${ }^{3}$.

There is evidence that supports the benefits of physical activity in childhood8. In order to increase participation in physical activity among schoolchildren it is important to know where, when and how these patterns evolve with age. So, the school is an appropriate and convenient environment for the promotion of physical activity and health ${ }^{9}$, because the children spend a large portion of their day in school ${ }^{10}$. School has an important role in the development of society ${ }^{11}$. Physical education and recess provide the two main opportunities for schoolbased physical activity ${ }^{12}$. Healthy People $2010^{13}$ recommend that physical education should be offered daily and consist of lessons that engage children in moderate to vigorous physical activity at least $50 \%$ of class time. Evidence suggests that schoolchildren who do not follow these recommendations ${ }^{14}$ do not obtain health benefits ${ }^{15}$. In the same way, recess is a good opportunity to increase the daily physical activity levels ${ }^{16}$. However, the studies that have attempted to evaluate it during recess have concentrated on specific age groups $^{16-19}$, ethnic differences ${ }^{20}$ in relationship with recommended guidelines ${ }^{21}$ or interventions for accumulating more physical activity ${ }^{21-23}$. To our knowledge, no cross sectional study in schoolchildren exist that covers six years and investigates differences between sex. The aim of this study was to describe the daily physical activity and physical activity during recess of Primary School children and their relationship with sex and age.

\section{SUBJECTS AND METHOD}

Design. A descriptive and crosssectional study was carried out, where the independent variables were age and sex, while the dependent variables were daily physical activity and physical activity during recess. 
Subjects. Seven schools from Extremadura (Spain) were invited to take part in the study. The schools were selected by accessibility and convenience (sampling which consisted of selecting schools the easiness or disposal to participate in estudio ${ }^{24}$ ). Initially, the parents of 913 children ( $84 \%$ of those invited) gave written informed consent to participate. 175 subjects were not included in the analysis due to failure to complete the general questionnaire (76 children), physical activity readiness questionnaire (63 children), or a problem with the accelerometers ( 36 children). The final sample therefore consisted of 738 children $(8.5 \pm 1.7$ years, range 6 to 11 years).

Instruments. All participants were assessed for height and weight. Daily physical activity of each child was measured using a validated questionnaire that was completed by the parents of each child ${ }^{25}$. The questionnaire measured all activities done (24 hours) during three days (Thursday, Friday and Saturday). These activities were divided into six categories: sleeping, very light activity (for activities such as computer or video games), light activities (e.g. cleaning), moderate activities (e.g. cycling), vigorous activity (e.g. running), very vigorous activities (e.g. playing football). To calculate the daily energy cost of each participant (MET/day) the hours used in each category were multiplied by the corresponding energy cost, according to reference tables ${ }^{26}$. Finally, the total daily energy cost was calculated using the average of three days.

Playground recess physical activity was measured using accelerometry. This method is commonly used in pediatric population ${ }^{27}$. Both longitudinal and cross-sectional studies have been conducted previously, to measure levels of physical activity in school cohorts $^{28}$ and to assess levels of physical activity in overweight and normal weight children ${ }^{29}$. The accelerometer used was a Caltrac (Hemokinetics, Madison, WI, USA) which was programmed to function as a physical activity monitor ${ }^{30}$. The Caltrac is an accelerometer that contains a piezoelectric bender element which assesses the movement in the vertical plane. The Caltrac adds and integrates the absolute values of acceleration versus curves and derives this into a numerical value (motion counts). This uniaxial accelerometer has been showed to be highly correlated with the triaxial accelerometer ${ }^{31}$. This methodology is similar to that used in other stu$\operatorname{dies}^{32-34}$.

Procedure. After initial contact with schools and the acceptance to participate in the study by the Head Teachers and School, an informed consent was given to parents/guardians. Those who signed the consent form were included in the study. The children were measured (height and weight) at the start of the day. Approximately ten minutes before recess, two researchers entered the classroom and distributed accelerometers to the participants who were seated at their desks. Each accelerometer was fixed to the waistband of the child's skirt or trousers before recess; the screen of the accelerometer was covered using black tape to prevent observation of the accelerometer measurement. Teachers and researchers monitored the recess ensuring that physical activity was not different from usual activities in order to prevent the manipulation of 
the accelerometer measurement. Upon returning to the classroom after recess time, students placed their accelerometers in a plastic collection container. The recess in all schools was of 30 minutes duration, was performed outdoors on sunny days and all age groups participated simultaneously, 40 children were assessed during each recess period.. The study was approved by the Commission of Bioethics at the University Extremadura and complied with the principles of the Declaration of Helsinki.

Data Analysis. The normality of the distributions was assessed by means of the Kolmogorov-Smirnov test and Levene test. A one-way analysis of variance (ANOVA) was used to test hypotheses about the equality of the means between groups for daily PA and recess physical activity. The Scheffé post-hoc test was used for comparisons between groups, age and sex. MANOVA was used to analyse the main and interaction effects of age and sex on variables. Additionally, pair-wise comparisons between groups were made through simple contrasts. A P-value $<.05$ was considered to be statistically significant. Confidence intervals and effect sizes of the differences were calculated $^{35}$. The Statistical Package for Social Sciences (SPSS for Windows, version 15.0) was used for all analyses.

\section{RESULTS}

Table 1 describes the characteristics of the sample. All variables met the criteria of normality $(0.643 \geq \mathrm{z} \leq 1.328$; $\mathrm{p}>0.05$ ) and homocesteidad $(0.207 \geq F \leq 2.322, p>0.05)$.

With regard to daily physical activity, boys reported higher levels than girls across all age groups, this difference was higher at seven years $(47.6 \pm$ 6.5 vs $42.6 \pm 6.4 \mathrm{MET} /$ days, $\mathrm{p}<0.001)$, eight years $(48.5 \pm 8.6$ vs. $41.9 \pm 4.6$ MET/day, $\mathrm{p}<0.001)$ and nine years $(49.8 \pm 8.3$ vs $44.1 \pm 5.9 \mathrm{MET} / \mathrm{day}$, $\mathrm{p}<0.001$ ) (Table 2). Whilst physical activity for boys did not vary across age groups $(p=0.190)$, there were lower levels of physical activity levels reported in 6,7 , and 8 year old girls $(42.1 \pm 4.8 \mathrm{METs} / \mathrm{day}, 42.6 \pm 6.4$ $\mathrm{MET} /$ day, 41.9 $\pm 4.6 \mathrm{MET} /$ day, respectively) compared to eleven year old girls $(45.0 \pm 8.1 \mathrm{MET} /$ day, $\mathrm{p}<0.001)$. The largest mean difference between boys and girls was in eight year olds $(48.5 \pm 8.6$ vs. $41.9 \pm 4.6$ METs, p $<0.001$, reported by boys and girls respectively). With regard to age in the whole sample, there were differences among schoolchildren in ten years compared with six $(47.5 \pm 9.4 \mathrm{vs}$ 44.2 $\pm 6.4 \mathrm{MET} /$ day, $\mathrm{p}<0.001)$ and eight years (47.5 \pm 9.4 vs $45.0 \pm 7.5 \mathrm{MET} /$ day; $\mathrm{p}<0.001)$ (Table 2).

Playground physical activity was higher for boys compared to girls at nine years $(28.4 \pm 12.0$ vs $23.7 \pm 11.8$ motion counts, $\mathrm{p}=0.039$ ), ten years $(28.5 \pm 10.8$ vs $23.7 \pm 10.0$ motion counts, $\mathrm{p}=0.014)$ and eleven years $(24.6 \pm 12.2$ vs $20.7 \pm 9.3$ motion counts, $\mathrm{p}=0.047$ ) (Table 2). Again, playground physical activity in boys does not vary across age group $(\mathrm{p}=0.156)$, while in girls physical activity was higher among eight year olds compared to eleven year olds $(28.0 \pm 10.5$ vs. $20.7 \pm 9.3$ motion counts, $p<0.001)$. Finally, in the whole sample there were differences between eight and eleven year olds $(29.0 \pm 11.7$ vs $22.7 \pm 11.0$ motion counts, $\mathrm{p}=0.008)$. There were no interactions between sex or age and daily physical activity or physical activity at recess. 
Table 1

Characteristics of sample

\begin{tabular}{|c|c|c|c|c|}
\hline Characteristics & $\begin{array}{l}\text { Children } \\
(\mathrm{N}=738)\end{array}$ & $\begin{array}{c}\text { Boys } \\
(\mathrm{n}=379)\end{array}$ & $\begin{array}{c}\text { Girls } \\
(\mathrm{n}=359)\end{array}$ & $p$ \\
\hline Kineanthopometric & & & & \\
\hline Height $(\mathrm{m})$ & $1.37 \pm 0,1$ & $1.37 \pm 0.3$ & $1.37 \pm 0.1$ & 0.570 \\
\hline Weight (kg) & $35.3 \pm 10,6$ & $35.4 \pm 10.7$ & $\begin{array}{c}35.2 \pm \\
10.6\end{array}$ & 0.649 \\
\hline BMI $\left(\mathrm{kg} / \mathrm{m}^{2}\right)$ & $18.3 \pm 3,4$ & $18.4 \pm 3.2$ & $18.3 \pm 3.0$ & 0.808 \\
\hline Practice sport out school(\%) & $\begin{array}{l}82.1 \\
17.9\end{array}$ & $\begin{array}{l}86.7 \\
13.3\end{array}$ & $\begin{array}{l}77.1 \\
22.9\end{array}$ & $\begin{array}{l}0.241 \\
0.393\end{array}$ \\
\hline Passive leisure (TV, co mputer...) (h/week) & $15.4 \pm 10.4$ & $16.1 \pm 8.8$ & $14.4 \pm 9.8$ & 0.005 \\
\hline Walking to school (\%) & $\begin{array}{l}60.6 \\
39.4\end{array}$ & $\begin{array}{l}61.1 \\
38.9\end{array}$ & $\begin{array}{l}58.2 \\
41.8\end{array}$ & $\begin{array}{l}0.439 \\
0.531\end{array}$ \\
\hline
\end{tabular}

Table 2

Daily physical activity (MET/day) and playground physical activity (motion counts) of children according to age and sex. P-value of ANOVA (difference by sex and age), interval confidence, effect size and p-value of MANOVA with Sheffe post-hoc.

Data are mean and standard desviation

\begin{tabular}{|c|c|c|c|c|c|c|c|c|}
\hline Variable & $\begin{array}{c}6 \text { years (a) } \\
(\mathrm{n}=122)\end{array}$ & $\begin{array}{c}7 \text { years }(b) \\
(n=131)\end{array}$ & $\begin{array}{c}8 \text { years }(\mathrm{c}) \\
(\mathrm{n}=126)\end{array}$ & $\begin{array}{c}9 \text { years }(d) \\
(n=117)\end{array}$ & $\begin{array}{c}10 \text { years }(\mathrm{e}) \\
(\mathrm{n}=125)\end{array}$ & $\begin{array}{c}11 \text { years }(\mathrm{f}) \\
(\mathrm{n}=117)\end{array}$ & $p$ & $\begin{array}{c}\text { Sheffé } \\
\text { post-hoc }\end{array}$ \\
\hline \multicolumn{9}{|l|}{ Daily PA (MET/day) } \\
\hline Children $(\mathrm{n}=738)$ & $44.2 \pm 6.4$ & $45.4 \pm 6.9$ & $45.0 \pm 7.5$ & $47.0 \pm 7.8$ & $47.5 \pm 9.4$ & $47.0 \pm 8.5$ & $<0.001$ & $\mathrm{a}, \mathrm{c}<\mathrm{e}$ \\
\hline Boys $(\mathrm{n}=\mathbf{3 7 9})$ & $46.2 \pm 7.0$ & $47.6 \pm 6.5$ & $48.5 \pm 8.6$ & $49.8 \pm 8.3$ & $49.5 \pm 8.9$ & $48.6 \pm 8.6$ & 0.190 & - \\
\hline Girls $(n=359)$ & $42.1 \pm 4.8$ & $42.6 \pm 6.4$ & $41.9 \pm 4.6$ & $44.1 \pm 5.9$ & $44.4 \pm 10.0$ & $45.0 \pm 8.1$ & $<0.001$ & $\mathrm{a}, \mathrm{b}, \mathrm{c}<\mathrm{f}$ \\
\hline Superior interval confidence & 1.08 & 1.16 & 1.36 & 1.19 & 0.92 & 0.82 & & \\
\hline Inferior interval confidence & 0.26 & 0.38 & 0.57 & 0.38 & 0.15 & 0.04 & & \\
\hline p-value, male vs. Female & 0.001 & $<0.001$ & $<0.001$ & $<0.001$ & 0.023 & 0.029 & & \\
\hline Effect size & 0.67 & 0.77 & 0.97 & 0.78 & 0.54 & 0.43 & & \\
\hline \multicolumn{9}{|l|}{ Playground PA (motion count) } \\
\hline Children $(n=738)$ & $25.0 \pm 11.0$ & $26.4 \pm 12.3$ & $29.0 \pm 11.7$ & $26.0 \pm 12.1$ & $26.2 \pm 10.6$ & $22.7 \pm 11.0$ & 0.008 & $c>f$ \\
\hline Boys $(n=379)$ & $27.1 \pm 10.4$ & $27.3 \pm 11.1$ & $30.1 \pm 12.9$ & $28.4 \pm 12.0$ & $28.5 \pm 10.8$ & $24.6 \pm 12.2$ & 0.156 & \\
\hline Girls $(n=359)$ & $23.3 \pm 9.9$ & $25.4 \pm 9.2$ & $28.0 \pm 10.5$ & $23.7 \pm 11.8$ & $23.7 \pm 10.0$ & $20.7 \pm 9.3$ & $<0.001$ & $c>f$ \\
\hline Superior interval confidence & 0.77 & 0.56 & 0.55 & 0.78 & 0.84 & 0.74 & & \\
\hline Inferior interval confidence & -0.03 & -0.19 & -0.20 & 0.01 & 0.07 & -0.04 & & \\
\hline p-value, male vs. Female & 0.125 & 0.294 & 0.315 & 0.039 & 0.014 & 0.047 & & \\
\hline Effect size & 0.37 & 0.19 & 0.18 & 0.39 & 0.46 & 0.35 & & \\
\hline
\end{tabular}

\section{DISCUSSION}

The results showed that boys did more daily physical activity than girls overall, as well as within each age group, this agrees with previous rese$\operatorname{arch}^{3,5,16,36,37}$. The major difference in age was observed at 8 years, where boys were more active that girls. These results are similar to a recent study ${ }^{38}$, where the daily physical activity was measured with accelerometers. Some studies have reported that maturity differences between sexes (females mature earlier than males) may be one reason why results consistently show that females are less active than males of the same chronological age ${ }^{39}$. However this study observed less daily physical activity levels in girls at younger ages, which suggest maturity may not be the only factor for the lower physical activity levels reported by girls. 
In the current study, no differences were found in daily physical activity or recess physical activity across age groups in boys. This finding is in contrast to studies that indicate that after age 9 there is a reduction in daily physical activity in boys ${ }^{32}$. On the other hand, 11-year old girls reported more daily physical activity than their 8-year old peers. However this difference was not reflected in their recess physical activity. This could be explained by physical activity for this age group occurring outside the playground ${ }^{40}$. On the other hand playground physical activity levels in both sexes are low, which is in agreement with previous research ${ }^{36}$. Another study ${ }^{38}$ suggest a decline in objectively measured overall physical activity levels between the ages of 6 and 9 years. This decline might be explained by increased time spend in scheduled time in school and non-sporting extracurricular activities (e.g. extra tuition, music lessons). It is possible that increased screen time (television, computer, console) such as that reported in the present study could at least partly explain this decline in physical activity. Too much screen time has been shown to influence the appearance of diseases such as obesity ${ }^{41}$. Therefore, the family environment might be considered an area of intervention to increasing physical activity in this age group, although a lack of high quality evaluations of interventions in such a setting hampers conclusions concerning effectiveness ${ }^{14}$.

On the other hand, school playgrounds provide important settings and opportunities for children to engage in physical activity. In the present study, from the age of nine, boys were more active than girls during recess. Reasons that explain these differences in playground physical activity are not completely clear ${ }^{42,43}$. Differences have been observed between the type of activity in which boys and girls participate $^{5,37,44}$. For example boys often participate in team activities such as handball, football, and basketball of moderate to high intensity, which often contained a competitive element, whereas girls generally participated in lower intensity activity such as talking, walking or skipping ${ }^{16}$. Generally, boys take part in more competitive activities and girls showed a preference for activities of cooperative character and view recess time as an opportunity to socialize with friends ${ }^{20}$. Another explanation of the differences found between the amount of physical activity engaged in during recess, might be that the accelerometer is more sensitive to the type and intensity of activities participated in by boys, this would exaggerate the differences found between sexes when using this measure ${ }^{40}$. Furthermore, the type of physical activity engaged in during recess time, might also be affected by cultural and environmental factors ${ }^{45}$. The analysis of recess PA revealed that there were no differences across age groups except among the group of schoolchildren aged 8 and 11 . This finding is in disagreement with other studies that have found a decrease in physical activity levels from the age of nine $^{23,32}$. One study ${ }^{40}$ explained this decrease in physical activity to a reluctance of wearing accelerometers. Likewise, according to previous rese$\operatorname{arch}^{38}$, gender differences in physical activities were most pronounced during school recess. These differences could also be due to the fact that some of the accelerometry studies focused on vigorous activity ${ }^{14,22}$, whereas the present data and other studies 
represent the total volume of physical activity accumulated during recess time, regardless of intensity ${ }^{16}$. Thus, this study suggests that strategies should be developed to increase physical activity at recess for girls over nine years of age. So, recess must be perceived not only as a leisure time, but also as an opportunity to promote a healthy and active lifestyle. Recess could be used by teachers to organize activities to suit the respective age, gender and interests groups of schoolchildren.

The present study has some limitations. First, the use of accelerometers could influence the physical activity at the playground; however the teachers of the children denied that the behavior of the children differed from normal. Second, as discussed above, the assessment of physical activity during recess was done one day, so that physical activity may have been affected. However, the sample size and the lack of highlighted unusual activity by the teachers may decrease the importance of this limitation.

Thus, this study examined the differences in daily physical activity and playground physical activity in primary schoolchildren and their relationship with age and sex. This is the first cross-sectional study that examines physical activity levels during recess between the ages of 6 and 11 years. The conclusion can be drawn from this work in relation to daily physical activity is that boys are more active than girls across all age groups (six to eleven years old), while that in recess physical activity the differences was only in boys between nine and eleven years of age.

\section{ACKNOWLEDGMENTS}

The authors wish to thank the Editorial Committee and anonymous reviewers who have helped to improve the quality of this article. Similarly, would like to thank students, parents/mothers and school participating in this study (CP Castra Caecilia in Cáceres, CP Cruz del Rio in Villanueva de la Serena, CP Hernán Cortés in Medellin, CP Manuel Mareque in Navaconcejo, CP Miralvalle in Plasencia; C Paideuterion in Cáceres, CP Santisimo Cristo del Risco in Sierra de Fuentes). Finally thank S. Vega and A.Hidalgo because their collaboration in data collection.

\section{BIBLIOGRAPHY}

1. Welsman JR and Armstrong N. The measurement and interpretation of aerobic fitness in children: current issues. J R Soc Med. 1996; 89:281-285.

2. World Health Organization. Global Recommendations on Physical Activity for Health. Berna (Suiza): World Health Organization 2010. Disponible en: http://www.who.int/dietphysicalactivity/factsheet rec ommendations/en/index.html. (consultado 14-082011).

3. Sallis JF, Prochaska JJ, and Taylor WC. A review of correlates of physical activity of children and adolescents. Med Sci Sports Exerc. 2000; 32:963-975.

4. Eaton DK, Kann L, Kinchen S, Shanklin S, Ross J, Hawkins J et al. Youth risk behavior surveillance - United States 2009. MMWR Surveill Summ. 2009; 59:1142 .

5. Perula de Torres LA, Lluch C, Ruiz Moral R, Espejo Espejo J, Tapia G and Mengual Luque P. Prevalencia de actividad física y su relación con variables sociodemográficas y ciertos estilos de vida en escolares cordobeses. Rev Esp Salud Pública. 1998; 72:233-244.

6. Sallis JF, Patterson TL, Buono MJ, Atkins CJ and Nader PR. Aggregation of physical activity habits in Mexican-American and Anglo families. J Behav Med. 1988; 11: 31-41.

7. Pugliese J, and Tinsley B. Parental socialization of child and adolescent physical activity: a metaanalysis. J Fam Psychol. 2007; 21:331-343. 
8. Strong WB, Malina RM, Blimkie CJ, Daniels SR, Dishman RK, Gutin B et al. Evidence based physical activity for school-age youth. J Pediatr. 2005; 146:732-737.

9. Sánchez Moreno A, Sánchez Estévez V, Canovas Valverde J, Barceló Apericio ML and Marset Campos P. Dimensiones educativas y sanitarias de la educación para la salud en la escuela: Una experiencia participativa y global en dos zonas de salud de Murcia. Rev Esp Salud Pública. 1993; 67:293304

10. Van Sluijs EM, McMinn AM and Griffin SJ. Effectiveness of interventions to promote physical activity in children and adolescents: systematic review of controlled trials. BMJ. 2007; 335:703716.

11. Gavidia Catalán V. La transversalidad y la escuela promotora de salud. Rev Esp Salud Púlica. 2001; 75:505-516.

12. Naylor PJ, and McKay HA. Prevention in the first place: schools a setting for action on physical inactivity. Br J Sports Med. 2009; 43:10-13.

13. United States Department of Health and Human Services. Healthy people 2010: understanding and improving health. Washington, DC: US Government Printing Office; 2000.

14. Stratton G. Promoting children's physical activity in primary school: an intervention study using playground markings. Ergo. 2000; 43:1538-1546.

15. McGall SE, McGuigan MR, and Nottle C. Contribution of free play towards physical activity guidelines for New Zealand primary school children aged 7-9 years. Br J Sports Med. 2011; 45:120-124.

16. Beighle A, Morgan CF, Le Masurier G, and Pangrazi RP. Children's physical activity during recess and outside of school. J Sch Health. 2006; $76: 516-520$.

17. Mota J, Silva P, Santos MP, Ribeiro JC, Oliveira J and Duarte JA. Physical activity and school recess time: differences between the sexes and the relationship between children's playground physical activity and habitual physical activity. J Sports Sci. 2005; 23:269-275.

18. Ridgers ND, and Stratton G. Physical activity during school recess: The Liverpool Sporting Playgrounds Project. Pediatr Exerc Sci. 2005; 17:281290.
19. Ridgers ND, Toth M and Uvacsek M. Physical activity levels of Hungarian children during school recess. Prev Med. 2009; 49:410-142.

20. Blatchford P, Baines E and Pellegrini A. The social context of school playground games: Sex and ethnic differences, and changes over time after entry to junior school. Br J Dev Psychol. 2003; 21:481-505.

21. Stratton G, and Mullan E. The effect of multicolor playground marking on children's physical activity level during recess. Prev Med. 2005; 41:828833.

22. Ridgers ND, Fairclough SJ, and Stratton G. Twelve-month effects of a playground intervention on children's morning and lunchtime recess physical activity levels. J. Phys Act Health. 2010; 7:167175.

23. Stellino MB, Sinclair CD, Partridge JA, McClary King K. Differences in children's recess physical activity: recess activity of the week intervention. J Sch Health. 2010; 80:436-444.

24. Borda M, Tuesca, T, Navarro E. Métodos cuantitativos. Herramientas para la investigación en salud ( $2^{\mathrm{a}}$ ed.). Barranquilla: Universidad del Norte; 2009 .

25. Cale L. Self-report measures of children's physical activity: Recommendations for future development and a new alternative measure. Health Educ J. 1994; 53:439-453.

26. Ainsworth BE, Haskell WL, Leon AS, Jacobs DR Jr, Montoye HJ, Sallis JF, et al. Compendium of physical activities: classification of energy costs of human physical activities. Med Sci Sports Exerc. 1993; 25:71-80.

27. Rowlands AV. Field methods of assessing physical activity and energy balance. In: Kinanthropometry and exercise physiology laboratory manual. Tests, Procedures and Data. R.G. Eston, and T. Reilly (Ed.). London: Routledge, 2001.p. 151-170.

28. Riddoch CJ, Bo Andersen L, Wedderkopp N, Harro M, Klasson-Heggebo L, Sardinha L et al. Physical activity levels and patterns of 9- and 15-yrold European children. Med Sci Sports Exerc. 2004; 36:86-92.

29. Deforche B, De Bourdeaudhuij I, D'Hondt E, and Cardon G. Objectively measured physical activity, physical activity related personality and body 
mass index in 6- to 10-yr-old children: a cross-sectional study. Int J Behav Nutr Phys Act. 2009; 6:19.

30. Sallis JF, Buono MJ, Roby JJ, Carlson D. and Nelson JA. The Caltrac accelerometer as a physical activity monitor for school-age children. Med Sci Sports Exerc. 1990; 22:698-703.

31. Eisenmann JC, Strath SJ, Shadrick D, Rigsby P, Hirsch $\mathrm{N}$ and Jacobson L. Validity of uniaxial accelerometry during activities of daily living in children. Eur J Appl Physiol. 2004: 91(2-3): 259-263.

32. Kimm SY, Glynn NW, Kriska AM, Fitzgerald SL, Aaron DJ, Similo SH et al. Longitudinal changes in physical activity in a biracial cohort during adolescence. Med Sci Sports Exerc. 2000; 32:14451454.

33. Sigmund E, Sigmundová D, El Ansari W. Changes in physical activity in pre-schoolers and firstgrade children: longitudinal study in the Czech Republic. Child Care Health Dev. 2009; 35:376382.

34. Saglam M, Arikan H, Savci S, Inal-Ince D, Bosnak-Guclu $\mathrm{M}$, Karabulut $\mathrm{E}$ et al. International physical activity questionnaire: reliability and validity of the Turkish version. Percept Mot Skills. 2010; 111:278-284.

35. Cohen L. Statistical power analysis for the behavioral sciences. Hillsdale, NJ: Lawrence Erlbaum Associates; 1988.

36. Troiano RP, Berrigan D, Dodd KW, Masse L, Tilert T and McDoweal M. Physical activity in the United States measured by accelerometer. Med Sci Sports Exerc. 2008; 40:181-188.

37. Nebot M, Comin E, Villalbí JR and Murillo C. Las actividad física de los escolares: Un estudio transversal. Rev Esp Salud Pública. 1991; 65:325331.

38. Nyberg GA, Nordenfelt AM, Ekelund U, and Marcus C. Physical Activity Patterns Measured by Accelerometry in 6- to 10-yr-Old Children. Med Sci Sports Exerc. 2009; 41:1842-1848.

39. Sherar LB, Esliger DW, Baxter-Jones AD and Tremblay MS. Age and gender differences in youth physical activity: does physical maturity matter? Med Sci Sports Exerc. 2007; 39:830-835.

40. Sallis JF, Alcaraz JE, McKenzie TL and Hovell MF. Predictors of change in children's physical acti- vity over 20 months. Variations by gender and level of adiposity. Am J Prev Med. 1999; 16:222-229.

41. American Academy of Pediatrics. Children, adolescents, and television. Pediatrics. 2001; 107:423-426.

42. Nettlefold L, McKay HA, Warburton DER, McGuire KA, Bredin SSD and Naylor PJ. The challenge of low physical activity during the school day: at recess, lunch, and physical education. Br J Sports Med. 2010

43. Ridgers ND, Stratton G and Fairclough SJ. Physical activity levels of children during school playtime. Sports Med. 2006; 36:359-371.

44. Macdonald D, Rodger S, Abbott R, Ziviani J and Jones J. I could do with a pair of wings: perspectives on physical activity, bodies and health from young Australian children. Sport Educ Soc. $2005 ; 10: 195-209$.

45. Sallis JF, Mckneize TL, Elder JP, Hoy PL, Galati T, Barry CC et al. Sex and ethnic differences in children's physical activity: discrepancies between self-report and objective measures. Pediatr Exerc Sci. 1998; 10:277-284. 